\title{
A NON-EXPERIMENTAL EVALUATION OF UNEMPLOYMENT RISK IN CRETE AND THE IONIAN ISLANDS: REGIONAL EVIDENCE FOR GREECE
}

\section{Stavros Rodokanakis*}

\section{Introduction}

The aim of the paper is to study the impact that education and training programmes (apprenticeship, intra-firm training, continuing vocational training-CVT, popular training) had on the labour market in the Greek regions of Crete and the Ionian Islands during the implementation of the Community Support Framework (CSF) CSF-1 (1989-93). Namely, we try to see whether the level of education itself and participation in training programmes increased the chances of finding a job. The vocational training programmes of the CSF-1 in the regions under examination started in March 1990 and ended in March 1994. During the examined time period, both regions belonged to Objective 1 of the EU Structural Funds. The total population of the above two regions constitutes $7.5 \%$ of Greece's total.

We work first at the regional level, and then at the urban, semi-urban and rural levels.

The main questions to be answered are:

(i) What are the social and demographic characteristics that increase the chances of someone in the examined population finding a job?

(ii) How does the participation in training courses affect the chances of getting an employment?

(iii) Whether university graduates, in contrast to most of the rest of the EU member states, face greater difficulties in finding a job than non-university graduates, as a series of studies (see Meghir et al., 1989; OECD, 1990; Iliades, 1995; IN.E./GSEE-ADEDY, 1999; Katsikas, 2005) for Greece conclude.

We test the human capital theory, which underpins many of the important developments in modern economics and provides one of the main explanations for wage and salary differentials by age and occupation, and the uneven incidence of unemployment by skill (education and training). We try to research whether the more educated and the more trained a person is, the higher the probability of him or her finding a job.

* University of Bath, Department of Social and Policy Sciences (srodo2003@yahoo.gr). 
Previous labour market studies for Greece were based on qualitative research and LFS aggregated data. The analysis of investigating the impact of training on the Greek labour market - at NUTS 2 level - is based on the micro-data of the Greek LFS. The access to the individual anonymised records of the Greek LFS was not allowed to researchers until the summer of 2005, due to the Data Protection Act.

Also, all training programmes in Greece are co-financed by the EU funds and so we try to see what happened with the EU money during the period of the CSF-1 in the domain of training. Thus, we do not simply research into the early 1990s but, for a specific reason, namely the management of EU funds in the first programming period. There is the opportunity for other researchers to compare the 2nd and 3rd CSFs with CSF-1 based on empirical analysis.

The article starts with the issue of over-education and why it is important to this research. Then, we examine the impact of training programmes on the employment prospects of individuals in the EU and the rest of the OECD according to a series of studies; the results are based on both cross-sectional and longitudinal data. We discuss the vocational training policies for the unemployed in Greece. Finally, we refer to the socio-economic characteristics of the examined regions and follow a logistic regression for the years 1988 and 1992 - based on micro-data of the Greek LFS - for the two regions under study. The article concludes with the impact of training on employment probability in Europe and the examined areas, and ends with some general comments on the merit and value of this study.

\section{The definition of educational mismatches and over-education}

A great deal of American and European empirical evidence, in fact, is now available on the subject of over-education. On the other hand, as Joop Hartog showed, "a solid relation (of the over-education / under-education literature) with a formal theory of the labour market is lacking" (Hartog, 1997). A further difficulty is the confusion between the term 'over-education' specifically, and very different notions like 'qualification inflation' or 'credentialism' (Green et al., 1999). According to human capital theory, over-education is not a permanent occurrence and is the result of a temporary poor match between the employer and the employee. This appears to go against the empirical evidence, which suggests there is always a large percentage of labour force that is over-educated (Green et al., 1999).

Hartog (1997) extensively surveyed the literature and found signs that over-education has grown in frequency over the years (i.e., especially since the 1970s, whilst under-education is less frequent, in Europe, anyway). In the UK, there is less evidence on under-education, but Sloane et al. (1995) showed a 17\% of under-education for the labour market generally. A reduced evaluation of $8-10 \%$ of under-education was shown by Groot and van den Brink (1997). In the vast majority of studies, over-education is a great deal more frequent than under-education and this outcome fits in with that of Green et al., 1999. 


\section{Why is over-education important to this research?}

According to the OECD (1990, p. 67, Table 2.3), in Greece - contrary to what happens in many other European countries - the unemployment rate of university graduates was higher than that of the less educated, whilst, mainly after the late 1980s, a lot of graduates of tertiary education, especially of certain old traditional specializations, faced problems of absorption into the labour market (Iliades, 1995). Also, according to Katsikas (2005), university graduates in Greece face greater difficulties finding a job in comparison to the less educated. Meghir et al. (1989) analysed the main determinants of female participation in the labour force and male unemployment duration in Greece using data from the 1981 Greek LFS. An interesting finding is that male unemployment duration increased with education. Also, according to the study of IN.E./GSEE-ADEDY (1999), based on the processing of ESYE (National Statistical Service of Greece) aggregated data, the probability of an unemployed person becoming long-term unemployed depends on his/her age, gender and family status. Contrary to the common perception, this probability did not depend on the level of education.

Greek farming and especially Greek industry consisted of many pre-eminently small businesses of traditional activities, which did not require administrative and technical staff with higher education and specialization (Kanellopoulos, 1984). Besides, the family character of many Greek businesses made their owners avoid hiring staff (including those with high qualifications) or implementing innovative ideas of highly skilled people, with the result that industry was unable to create enough new positions for people with relatively high specialization and unable to absorb the increased numbers of graduates (Kanellopoulos, 1984). Exactly the opposite happened in the public sector, where many new positions were created to absorb unemployed graduates. Although this waiting (queuing for a public sector job) raised the apparent unemployment of graduates (see, for instance, Krueger and Summers, 1987, p. 44), some of them held tempor $\neg$ ary jobs, often in the concealed economy (Glytsos, 1990). Moreover, the public sector limits its action to essentially bureaucratic competence and activities or the provision of non-exchangeable services internationally. Greece seems to manifest over-edu $\neg$ cation by any of the criteria mentioned above. The relative remuneration of university graduates was decreasing through time, mainly because of their over-supply (Glytsos, 1990).

For more information on the causes of graduate unemployment, see Johnes et al., 1987; Sanyal, 1987; Dolton and Vignoles, 2000.

\section{The human capital approach and the human capital theory}

During the late 1950s and early 1960s, the current neoclassical theory of the labour market emerged with the development of the human capital theory. Gary Becker (1964 - 2nd ed., 1975) published a book with the title "Human Capital", which developed a theory of human capital formation and analysed the rate of return on investment in education and training. However, investment in human capital remains a controversial issue (Woodhall, 1987). 
Whilst the human capital literature has highlighted a number of productivityrelated characteristics, human capital theorists place most emphasis on the importance of education and training as the main component of productivity (Blaug, 1975). Education, it is suggested, provides the basic skills of reading and writing, cognitive skills, and the "ability to learn" which will increase an individual's productivity in all jobs (general human capital), whilst vocational education, on the other hand, will increase an individual's productivity in a narrower range of jobs by providing more specific skills (specific human capital).

Becker (1962) distinguishes between general and specific human capital of workers, and within specific human capital, between employer- and employee-financed on-the-job training. Most broadly, the theory of specific human capital predicts that where the fixed costs of employment, due to on-the-job training, are the greatest, unemployment is the lowest (Rees, 1973, pp. 118-20).

Following Becker's (1964) analysis of the economic role of human capital, particularly education, there is now a considerable amount of empirical research on the closely related topics of education and skills (see Prais, 1995; Murray and Steedman, 1998) and, more specifically, the increasing role of skilled labour in the economy (Berman et al., 1994; Machin, 1996; Green et al., 1998; Machin and van Reenen, 1998).

\section{Impact of training at micro-economic level}

The early European evaluation studies are mostly characterized by the fact that research was not based on longitudinal and non-experimental data, as is the norm in the secondgeneration studies (see section 5.2), but on cross-sectional and (quasi) experimental data. Experimental evaluations are common in the U.S. but scarce in Europe (Bjorklund and Regner, 1996). The micro-economic studies on active labour market policies (ALMPs) were effectively summed up in OECD (1993a) and Fay (1996). Regarding training, the basic conclusion was a frequently weak return to the training of the unemployed. In the majority of cases, the most significant force decreasing the return was deadweight (i.e., a trained job-hunter is taken on but would have been employed in any case without training) (Jackman et al., 1996).

\subsection{The findings of European training evaluations (first-generation studies)}

Among the ALMPs, the greatest advance has been in the evaluation of training programmes, whilst the majority of the training studies focused on the impact of training on future remuneration or on the likelihood of re-employment. The impact on the duration of the following employment period, too, has just been examined in studies done lately (e.g. Kaitz, 1979; Ridder, 1986; Card and Sullivan, 1988; Ham and Lalonde, 1991; Gritz, 1993; Bonnal et al., 1994; Torp, 1994; Zweimuller and WinterEbmer, 1996) - it is important to separate the length of employment from the duration of job tenure (Cockx et al., 1998).

Examination of accessible micro studies on training forces us to realize that it has been remarkably difficult to be clear about the foreseeable positive impact on those 
taking part (Jackman, 1995). It could be thought more extraordinary, according to Calmfors and Skedinger (1995), in view of the powerful theoretical points suggesting a positive impact when programmes were concentrated on a set of outsiders like these, that there is no more definite evidence on the impacts of centring on the young.

A large number of different sorts of training programmes and their impacts were studied by OECD (1993a). In general, it was found that programmes aimed at a few people only whose requirements are easily recognizable and at quite a high cost per person, frequently seemed to succeed relatively well in improving the remuneration and job possibilities of a number of the participants (this might account for the fact that training programmes in Norway, which were not that large, seemed to have succeeded much more effectively than in Sweden; Calmfors, 1995). In contrast, wider programmes involving more participants at quite a low cost per person normally appeared to make almost no difference (if any) to the prospects of those involved (Jackman, 1995). According to Rosholm and Skipper (2003), training raises the employment rate of participants but this effect disappears over time and this would indicate a locking-in effect.

These findings can be explained in different ways. One is that the characteristics of the unemployed differ to a great extent and taking into account their age, education and occupational backgrounds, just a few were able to gain from more training. Therefore, the only training programmes that had economic returns were those aimed at particular groups. Another explanation is that due to greater returns to training, only programmes with large inputs, i.e., targeted programmes, succeed. For instance, this could apply where the trainees are not used to the kind of skills they are learning, or for those not used to gaining skills by formal means (Jackman, 1995).

It follows that a labour market policy desirous of putting all unemployed people on a programme, or giving them temporary work, cannot be largely made up of effective training programmes (OECD, 1993b; Calmfors, 1994).

\subsection{Findings of recent European Programme evaluation on training (second-generation studies)}

In contrast to the early European evaluation studies - cited in section 5.1 - cross-sectional data is hardly to be found and training research in Europe has replaced it with the more useful longitudinal data, allowing for the possibility that impact assessments will be more robust (Kluve and Schmidt, 2002). Namely, the studies in section 5.2 examined the same population groups over time, except those of Winter-Ebmer (2006) and Cueto and Mato (2009), which used only one reference year in their research; also, only one study (that of Malmberg-Heimonen and Vuori, 2005) used experimental data.

These results show that the more expensive programmes having a significant amount of training appear to be most effective at increasing employment prospects (see Kluve et al., 1999; Brodaty et al., 2001; van Ours, 2001; Kluve and Schmidt, 2002; Raaum and Torp, 2002). Lately, national studies do not all find positive impacts (Gerfin and Lechner, 2000; Regner, 2002); but bearing in mind that job creation and subsidies for employment in the public sector usually do not succeed (Kluve et al., 1999; Brodaty 
et al., 2001), especially if their one aim is to remove unemployed people from the register (Lechner, 2000), training seems to have a significant impact.

Concerning the most recent research (Weber and Hofer, 2003; Graversen, 2004; Graversen and Jensen, 2004; Hujer et al., 2004; Rosholm and Svarer, 2004; Centeno et al., 2005 - on earnings as well; Hogelund and Holm, 2005; Aakvik and Dahl, 2006), there is no impact of training on employment probability on the European labour markets. Also, according to a series of studies (Lechner et al., 2005 - on earnings as well; Malmberg-Heimonen and Vuori, 2005; Steiger, 2005; Lechner et al., 2007 on earnings as well; Cueto and Mato, 2009 - a locking-in effect of trainees is shown that may be decreasing labour mobility) the employment effects of training are mixed; namely, there are positive and negative results. Furthermore, recent research on Europe has also found that training has positive effects on employment probability, although in some cases more for specific age groups or areas [Cockx, 2003; Hamalainen and Ollikainen, 2004; Leetmaa and Vork, 2004; Albrecht et al., 2005 - on employment effects for young men (research on earnings as well, but no impact on income effects); Arellano, 2005 - higher positive effects for women than for men; Cavaco et al., 2005; Fitzenberger and Speckesser, 2005 - more in West Germany than in East Germany; Kluve et al., 2005; Lorentzen and Dahl, 2005 - but modest effects and only on earnings; Stenberg, 2005; Winter-Ebmer, 2006 - for men and on earnings as well; Mato and Cueto, 2008 - but no effects on earnings].

In conclusion, up-to-date evaluation studies point to minor impacts of European training policies and they are most likely less significant and not always as positive as those responsible for designing them had wished. Although the cross-national figures show a few positive results of programmes, it is impossible to disregard the more negative results. The findings allow us to conclude that training programmes seem to have some positive effects on employment and no effects on earnings. Moreover, effects diminish over time. The negative effects reported by several evaluations can be explained, on the one hand, by a locking-in effect, and on the other, by the fact that some participants seem to enrol in training merely in order to collect unemployment insurance benefits (Cueto and Mato, 2009). The conclusions based on the recent studies are somewhat similar to those of Heckman et al. (1999) and Stanley et al. (1999) for the U.S.

\section{Vocational training policies for the unemployed in Greece}

The structure of expenditures on "active" interventions in 1997 shows that the level of expenditures in Greece $(0.35 \%)$, as a percentage of the GDP, is behind that of the EU-15 average (1.13\%) concerning all specific interventions, with the exception of "measures for the young" (youth vocational education and training, etc.; 0.10\%) which are comparable to the European average $(0.13 \%)$. Furthermore, there is an extremely low level of expenditures on the training of adults $(0.06 \%$ for Greece in comparison to $0.29 \%$ for the EU-15) (OECD, Employment Outlook, 1999).

The system of CVT in Greece was developed mainly due to its incorporation in Community funding programmes (Iliades, 1995; Chletsos, 1998; Papakonstantinou, 1998). Policies concerned with training and retraining of the unemployed have 
been confined to continuing training programmes. Vocational training programmes for the unemployed were wholly unconnected with employment policies, and were thus wasteful of training resources (Gravaris, 1991, p. 37; Christodoulakis and Kalyvitis, 1995; Balourdos and Chryssakis, 1998). This is reflected in the fact that the unemployment rate for those (20-29 years old) with complementary vocational training in Greece was $20 \%$, compared to $14 \%$ for those with only compulsory schooling; the corresponding figures for the EU were $11.5 \%$ and $23.5 \%$ ((Economic and Social Committee of Greece, 1998, p. 31).

Particularly with regard to training programmes for the unemployed in Greece, the method of identifying skill requirements, on the basis of which the programmes were offered, was wholly inadequate. It was based on changes in labour force categories derived from the LFS, on estimates of the impact of investment programmes on employment (where these existed or where such estimates were possible) and on Job Market Surveys. These last record shortages of skills on the basis of company estimates of their own shortages, which were often inaccurate or did not correspond to the capacity of the firms to utilise the skills demanded (Linardos-Rylmon, 1998).

\section{The Region of Crete}

The Region of Crete contains the NUTS-3 areas of Iraklio, Lasithi, Rethymno and Chania. In 2001, the per capita GDP was equal to $67 \%$ of the EU-15 average $(69 \%$ for Greece as a whole), whereas in 2003 the regional GDP per head was $97 \%$ of the country's mean ( $98 \%$ in 1995$)$ and $78 \%$ of the EU-25 mean $(80.9 \%$ for the country as a whole). With Iraklio as its centre, $5.5 \%$ of the country's population is concentrated in the region with a distinct upward trend, noting that between the censuses of 1991 and 2001 , the region had the second highest rate of population increase $(11.3 \%)$ nationally after the Southern Aegean. It produces 5.3\% of the national GDP, $7.9 \%$ of the agricultural produce, $1.3 \%$ of manufacturing and $5.9 \%$ of services. Seventy-five percent of its produce comes from services, with its significant role in tourism, noting that $15 \%$ of its gross product stems from hotels and restaurants (2003). It accounts for $7.5 \%$ of cultivated land in the country and $35 \%$ of total olive oil production (first in the country in 2001). Unemployment in Crete fell for the third consecutive year by 0.2 units in 2001 , to $6.7 \%$ of the workforce ( $10.5 \%$ for the whole of Greece), the second lowest proportion nationally (source: www.economics.gr).

\section{The Region of the Ionian Islands}

The Region of Ionian Islands contains the NUTS-3 areas of Zakynthos, Corfu, Kefallinia and Lefkada. The region consists of 32 small and big islands, but only 13 of them are inhabited (the four aforementioned islands plus Antipaxoi, Ereikousa, Ithaka, Kalamos, Kastos, Mathraki, Meganisi, Othonoi and Paxoi). Between the censuses of 1991 and 2001, the population rose by $9.9 \%$, the third largest rise nationally after the Southern Aegean and Crete (source: www.economics.gr).

With Corfu as its centre, the region is inhabited by $2 \%$ of the country's population and produces $1.7 \%$ of the GDP (2003). In 2001, the per capita GDP was equal to $61 \%$ 
of the EU-15 average (69\% for Greece as a whole), whereas in 2003 , the regional GDP per head was $87 \%$ of the country's mean ( $85 \%$ in 1995 ) and $71 \%$ of the EU-25 mean $(80.9 \%$ for the country as a whole). The region produces $2 \%$ of the country's agricultural produce, $0.15 \%$ of manufacturing production and $2 \%$ of services. Eighty percent of the region's produce comes from services, with an important contribution of tourism, considering that $20 \%$ of the regional GDP stems from hotels and restaurants (the second highest proportion in the country after that of Southern Aegean) (2003 data). In 2001 , it accounted for $2 \%$ of cultivated land in the country. Unemployment in the region rose by 1.2 units in 2001 to $10.2 \%$ of the workforce, the largest rise in the country (11.3\% in 2003; $10.5 \%$ for the whole of Greece) (source: www.economics.gr).

\section{Numbers of records in the LFS samples}

The questionnaire of the European (and Greek) LFS was greatly modified in 1992 (Felstead et al., 1998). The originality of this research is that we use individual anonymised records (micro-data) of the LFS for both the employed and the unemployed (about $1.5 \%$ of the total population of each region).

Table 1 shows the numbers of records eligible for analysis in the LFS samples for the two regions under examination in 1988 and 1992. Apart from the system missing records, following the age limitation (15-64 years old) and removing the non-active population, we ended with the following numbers of records eligible for analysis in each region (in the spring, namely from the 14th to 26th week of the year):

\section{Table 1}

Numbers of records eligible for analysis in the LFS samples

\begin{tabular}{|c|c|c|}
\hline Year & Region & No. of records \\
\hline \multirow{2}{*}{1988} & Crete & $\mathbf{2 , 7 2 6}$ \\
\cline { 2 - 3 } & Ionian Islands & 1,103 \\
\hline \multirow{2}{*}{1992} & Crete & $\mathbf{2 , 4 6 2}$ \\
\cline { 2 - 3 } & Ionian Islands & 994 \\
\hline
\end{tabular}

\section{The logistic regression based on the micro-data of the Greek LFS}

The basic aim of the econometric analysis is to test the impact that training programmes (apprenticeship, intra-firm training, CVT, popular training) and level of education had on people's job prospects in the Regions of Crete and the Ionian Islands during the implementation of the CSF-1 (1989-93), accounting for demographic characteristics such as age, gender, marital status and area of residence. We try to see whether participation in training programmes and level of education increased the chances of finding a job. In the paper, we use a logistic regression model for studying differences between those that did participate in training programmes and those that did not. Regression models allow group comparisons adjusting for demographic and socio-economic 
variables. It should be noted that regression-adjusted comparisons may still provide misleading results when other important variables that might have an effect are omitted.

The dependent variable takes two possible values (employed versus unemployed). The explanatory variables (six for 1992 and five for 1988) are the participation in training courses (with five categories, including the four types of training completed, as mentioned above, and non-participation in training courses as the reference category), six levels of education, gender, age level (four categories), marital status and place of residence (urban areas, semi-urban areas, and rural areas).

The effect of demographic variables such as age, gender, marital status, place of residence, as well as level of education and participation in training programmes on the employment status, is investigated with a logistic regression model due to the categorical nature of the dependent variable. The logistic regression model is written as:

$$
\operatorname{logit} \mathrm{P}\left(\mathrm{y}=1 \mid \mathrm{x}_{1}, \ldots, \mathrm{x}_{\mathrm{k}}\right)=\log \left[\frac{\mathrm{P}\left(\mathrm{y}=1 \mid \mathrm{x}_{1}, \ldots, \mathrm{x}_{\mathrm{k}}\right)}{1-\mathrm{P}\left(\mathrm{y}=1 \mid \mathrm{x}_{1}, \ldots, \mathrm{x}_{\mathrm{k}}\right)}\right]=\beta_{0}+\sum_{\mathrm{k}=1}^{\mathrm{K}} \beta_{\mathrm{k}} \mathrm{x}_{\mathrm{k}}
$$

where $\mathrm{P}\left(\mathrm{y}=1 \mid \mathrm{x}_{1}, \ldots, \mathrm{x}_{\mathrm{k}}\right)$ and 1- $\mathrm{P}\left(\mathrm{y}=1 \mid \mathrm{x}_{1}, \ldots, \mathrm{x}_{\mathrm{k}}\right)$ denote the conditional probability for a randomly selected individual to be 'unemployed' and 'employed' respectively. The coefficient $\beta_{k}$ denotes the effect that a unit increase in the explanatory variable $x_{k}$ has on the log odds of being 'unemployed' than 'employed' controlling for all other variables in the model, and $\beta_{0}$ is the intercept of the model and the value of the logit when all the explanatory variables take the zero value. More specifically, a unit increase in the explanatory variable $x_{k}$ multiplies the odds by $e^{\beta_{k}}$ controlling for all other variables in the model.

Solving the above formula with respect to the conditional probability, we have:

$$
\mathrm{P}\left(\mathrm{y}=1 \mid \mathrm{x}_{1}, \ldots, \mathrm{x}_{\mathrm{k}}\right)=\frac{\mathrm{e}^{\beta_{0}+\sum_{\mathrm{k}=1}^{\mathrm{K} \beta_{\mathrm{k}} \mathrm{x}_{\mathrm{k}}}}}{1+\mathrm{e}^{\beta_{0}+\sum_{\mathrm{k}=1}^{\mathrm{K}} \beta_{\mathrm{k}} \mathrm{x}_{\mathrm{k}}}}
$$

Due to data limitations, we cannot explore the impact that the duration of courses, thematic fields, number of participants, and duration of unemployment period of the trainees have on unemployment. Another limitation of the research is that the data available are cross-sectional rather than longitudinal and therefore we cannot study any population changes across time. The Greek LFS data are non-experimental. 


\subsection{Description of the variables}

We now define the complete list of variables together with their coding values that we use in the model.

\section{Dependent variable}

Employment Status (STA1) (Unemployed =1, Employed $=0$ )

\section{Explanatory variables}

The reference category of each variable is underlined.

1) Gender (STA 2) $($ Female $=1$, Male $=0)$

2) Marital status (STA 3) $($ Married or divorced or widows $=1$, Non-married $=0)$

3) Level of education

$\underline{\text { STA } 8 \mathrm{~A}=\text { University graduates }}$

STA 8A1 $=$ MSc or PhD holders

STA 8B = Technological Educational Institution (TEI) graduates

STA 8C $=$ Lyceum (12 years of schooling) or incomplete University graduates

STA $8 \mathrm{C} 1=$ High-school graduates (9 years: compulsory education)

STA 8D = Primary school graduates or incomplete primary school or never at school.

4) Urbanization level of settlement system

STA 9C $=$ Urban areas

STA 9D $=$ Semi-urban areas

$\underline{\text { STA 9E }=\text { Rural areas }}$

5) Participation in training course(s) in the past

STA 26A $=$ Apprenticeship

STA 26B $=$ Intra-firm training

STA $26 \mathrm{C}=$ Continuing vocational training $(\mathrm{CVT})$

STA 26D $=$ Popular training

$\underline{\text { STA } 26 \mathrm{E}=\text { Non-participation in the past in training course(s) }}$

6) Age groups

$\underline{\text { STA } 40 \mathrm{~A}=15-24 \text { years old }}$

STA 40D $=25-34$ years old

STA 40E $=35-44$ years old

STA 40C $=45-64$ years old

The base (or reference) categories are those with which the rest of the corresponding variables are compared. The reference categories are chosen so as to match the needs of the research. 
The working age population is between 14-65 years old. However, marking in SPSS the ages 14 and 65 we also include those who are 13 and 66 years old something which we want to avoid; so, we include people from 15 to 64 .

The variable "participation in training course(s) in the past" first appeared in the 1992 questionnaire; it means that the interviewee had completed one or more training courses. This is also an indication of the attitude towards training in Greece at the beginning of the 1990s. The duration of apprenticeship and intra-firm training had to be at least one year according to the questionnaire of the Greek LFS. The term "popular training" (laiki epimorphosi in Greek) means training courses intended mainly for elderly people independently of their level of education, where the curriculum includes largely courses in general knowledge.

\subsection{Results for Crete}

Tables 2 and 3 present the results of the logistic regression for Crete for 1988 and 1992. In both years, women, non-married individuals, people who lived either in urban areas or semi-urban areas were more likely to be unemployed than men, married people, and those in rural areas. The results are in accordance with the family strategies and the gender roles in traditional families in this region, as well as with the unequal opportunities and discrimination against women by companies. The higher probability of women in relation to men could also be explained by the fact that women often join the labour market earlier in relation to men. Compulsory military service and further education (not a likely explanation anymore) were the major reasons for men's delay in entering the labour market. Extended family protection, with a view to preparation for entry into the labour market, applies to both sexes, of course. The effect of urbanisation level can be explained since in the Greek agrarian sector unemployment was not properly counted, because hidden unemployment is quite high. Also in both years, people in the age group of 15-24 years old were more likely to be unemployed than people at the age of 25 to 64 .

In addition, for 1988, significant differences in education have been found only between primary school graduates and university graduates indicating that primary school graduates were less likely to be unemployed than university graduates, whereas all the rest of the educational variables are statistically non-significant in both 1988 and 1992.

Most importantly, none of the four types of training programmes seem to reduce the odds of unemployment. The same results on training were found for other Greek regions as well (see Rodokanakis, 2009a and 2009b; Rodokanakis and Tryfonidis, 2009; Rodokanakis, 2010a and 2010b; Rodokanakis and Moustaki, 2010). Also, the results of the logistic regression confirm the conclusions of the various studies for the limited impact of vocational training in Greece (see section 6). 


\subsubsection{Results for Crete, 1988}

Table 2 (parameter estimates $b_{k}$, standard errors (s.e.). p-value. exponent of $b_{k}$ )

\begin{tabular}{|l|c|c|c|c|c|c|}
\hline Variables & \multicolumn{1}{|c|}{ B } & S.E. & Wald & df & Sig. & Exp(B) \\
\hline Gender & 1.094 & .226 & 23.405 & 1 & .000 & 2.985 \\
\hline Marital status & -.784 & .277 & 8.045 & 1 & .005 & .456 \\
\hline Aged 25-34 & -.667 & .293 & 5.173 & 1 & .023 & .513 \\
\hline Aged 35-44 & -1.088 & .382 & 8.105 & 1 & .004 & .337 \\
\hline Aged 45-64 & -1.638 & .436 & 14.098 & 1 & .000 & .194 \\
\hline MSc or PhD holders & 1.333 & 1.149 & 1.346 & 1 & .246 & 3.793 \\
\hline TEl graduates & .693 & .395 & 3.079 & 1 & .079 & 2.000 \\
\hline 12 years of schooling & .362 & .332 & 1.187 & 1 & .276 & 1.436 \\
\hline 9 years: compulsory education & -.682 & .488 & 1.954 & 1 & .162 & .505 \\
\hline $\begin{array}{l}\text { Primary school graduates } \\
\text { and below }\end{array}$ & -.755 & .370 & 4.161 & 1 & .041 & .470 \\
\hline Urban areas & 1.379 & .313 & 19.429 & 1 & .000 & 3.970 \\
\hline Semi-urban areas & 1.057 & .392 & 7.265 & 1 & .007 & 2.878 \\
\hline Constant & -3.173 & .446 & 50.725 & 1 & .000 & .042 \\
\hline
\end{tabular}

\subsubsection{Results for Crete, 1992}

Table 3 (parameter estimates $b_{k}$, standard errors (s.e.). p-value. exponent of $b_{k}$ )

\begin{tabular}{|l|r|r|r|r|r|c|}
\hline Variables & \multicolumn{1}{|c|}{ B } & \multicolumn{1}{c|}{ S.E. } & \multicolumn{1}{c|}{ Wald } & df & \multicolumn{1}{c|}{ Sig. } & Exp(B) \\
\hline Gender & 1.248 & .238 & 27.607 & 1 & .000 & 3.485 \\
\hline Marital status & -.861 & .325 & 7.037 & 1 & .008 & .423 \\
\hline Aged 25-34 & -1.847 & .320 & 33.393 & 1 & .000 & .158 \\
\hline Aged 35-44 & -1.801 & .417 & 18.671 & 1 & .000 & .165 \\
\hline Aged 45-64 & -2.424 & .485 & 24.999 & 1 & .000 & .089 \\
\hline MSc or PhD holders & -16.822 & $1.784 \mathrm{E} 4$ & .000 & 1 & .999 & .000 \\
\hline TEl graduates & .774 & .527 & 2.154 & 1 & .142 & 2.168 \\
\hline 12 years of schooling & .368 & .436 & .714 & 1 & .398 & 1.445 \\
\hline 9 years:compulsory education & .202 & .495 & .166 & 1 & .683 & 1.224 \\
\hline Primary school graduates and & -.299 & .457 & .428 & 1 & .513 & .741 \\
\hline below & 1.693 & .330 & 26.240 & 1 & .000 & 5.434 \\
\hline Urban areas & 1.095 & .436 & 6.311 & 1 & .012 & 2.988 \\
\hline Semi-urban areas & -19.156 & $1.041 \mathrm{E} 4$ & .000 & 1 & .999 & .000 \\
\hline Apprenticeship & -16.762 & $2.835 \mathrm{E} 4$ & .000 & 1 & 1.000 & .000 \\
\hline Intra-firm training & 1.210 & 1.665 & .528 & 1 & .467 & 3.354 \\
\hline CVT & -19.082 & $2.842 \mathrm{E} 4$ & .000 & 1 & .999 & .000 \\
\hline Popular training & -3.070 & .539 & 32.419 & 1 & .000 & .046 \\
\hline Constant & & & & & \\
\hline
\end{tabular}




\subsection{Results for the Ionian Islands}

Tables 4 and 5 present the results of the logistic regression in the Ionian Islands for 1988 and 1992. The results for gender and marital status are mixed. In both years, people in the age group of 15-24 years old were more likely to be unemployed than people at the age of 35 to 64; the results are mixed for the age group of 25-34.

The findings concerning the urbanisation level are mixed. In 1988, people who lived in urban areas were more likely to be unemployed than those in rural areas; in this case, the effect of place of residence can be explained since unemployment was not properly counted in the Greek agrarian sector. Living in semi-urban areas was not found statistically significant. In 1992, people who lived in urban or semi-urban areas were less likely to be unemployed than those in rural areas.

Concerning education, for 1988, all educational variables are statistically non-significant. On the contrary, in 1992, primary school graduates were less likely to be unemployed than university graduates; also, TEI and high-school graduates were more likely to be unemployed than university degree holders.

Furthermore, in the Region of the Ionian Islands, only apprenticeship was found to be statistically significant; namely, the participants in this kind of training courses are more likely to be unemployed than those who have not participated in any type of training programmes.

10.3.1 Results for the Ionian Islands, 1988

Table 4 (parameter estimates $b_{k}$, standard errors (s.e.). p-value. exponent of $b_{k}$ )

\begin{tabular}{|l|r|r|r|r|r|c|}
\hline Variables & \multicolumn{1}{|c|}{ B } & \multicolumn{1}{c|}{ S.E. } & Wald & df & Sig. & Exp(B) \\
\hline Gender & .451 & .359 & 1.574 & 1 & .210 & 1.569 \\
\hline Marital status & -.017 & .465 & .001 & 1 & .971 & .983 \\
\hline Aged 25-34 & -.631 & .481 & 1.717 & 1 & .190 & .532 \\
\hline Aged 35-44 & -2.169 & .702 & 9.537 & 1 & .002 & .114 \\
\hline Aged 45-64 & -1.862 & .656 & 8.048 & 1 & .005 & .155 \\
\hline MSc or PhD holders & .000 & 1.274 & .000 & 1 & 1.000 & 1.000 \\
\hline TEl graduates & 1.305 & .783 & 2.778 & 1 & .096 & 3.689 \\
\hline 12 years of schooling & -17.807 & $4.712 \mathrm{E} 3$ & .000 & 1 & .997 & .000 \\
\hline 9 years: compulsory education & -.067 & .818 & .007 & 1 & .935 & .935 \\
\hline $\begin{array}{l}\text { Primary school graduates } \\
\text { and below }\end{array}$ & 1.251 & 423 & 8.746 & 1 & .003 & 3.493 \\
\hline Urban areas & .369 & .544 & .460 & 1 & .497 & 1.446 \\
\hline Semi-urban areas & -3.121 & .892 & 12.255 & 1 & .000 & .044 \\
\hline Constant & -3.173 & .446 & 50.725 & 1 & .000 & .042 \\
\hline
\end{tabular}


10.3.2 Results for the Ionian Islands, 1992

Table 5 (parameter estimates $b_{k}$, standard errors (s.e.). p-value. exponent of $b_{k}$ )

\begin{tabular}{|l|r|r|r|r|r|c|}
\hline Variables & \multicolumn{1}{|c|}{ B } & \multicolumn{1}{c|}{ S.E. } & \multicolumn{1}{c|}{ Wald } & df & Sig. & Exp(B) \\
\hline Gender & 1.598 & .056 & 826.509 & 1 & .000 & 4.944 \\
\hline Marital status & -.811 & .065 & 157.139 & 1 & .000 & .445 \\
\hline Aged 25-34 & -.668 & .064 & 107.193 & 1 & .000 & .513 \\
\hline Aged 35-44 & -1.595 & .085 & 349.328 & 1 & .000 & .203 \\
\hline Aged 45-64 & -2.987 & .133 & 503.260 & 1 & .000 & .050 \\
\hline TEl graduates & .489 & .121 & 16.452 & 1 & .000 & 1.630 \\
\hline 12 years of schooling & -.020 & .088 & .054 & 1 & .816 & .980 \\
\hline 9 years: compulsory education & .682 & .099 & 47.620 & 1 & .000 & 1.978 \\
\hline $\begin{array}{l}\text { Primary school graduates and } \\
\text { below }\end{array}$ & -1.032 & .096 & 115.379 & 1 & .000 & .356 \\
\hline Urban areas & -.336 & .060 & 31.731 & 1 & .000 & .714 \\
\hline Semi-urban areas & -.260 & .075 & 12.061 & 1 & .001 & .771 \\
\hline Apprenticeship & 1.538 & .152 & 102.861 & 1 & .000 & 4.654 \\
\hline Intra-firm training & -18.231 & $2.550 E 3$ & .000 & 1 & .994 & .000 \\
\hline CVT & -15.170 & $3.297 E 3$ & .000 & 1 & .996 & .000 \\
\hline Constant & -2.354 & .105 & 502.858 & 1 & .000 & .095 \\
\hline
\end{tabular}

\subsection{Interaction effect among variables}

Only for the 1992 sample did we fit the interaction effects between training and urbanisation level, and between training and level of education. Interaction terms were not found to be statistically significant in either region. Therefore, the variable "training" does not alter the relationship between unemployment and education, as well as unemployment and urbanisation level. In other words, the chances of finding a job do not change when we count training as an additional qualification in relation to place of residence and level of education.

\section{Conclusions}

A significant number of researchers making use of accessible data and studies to examine the potential impacts of training on employment have been referred to. In spite of being restricted to only a small number of nations, micro-economic studies of effect evaluations indicate that some programmes have managed to noticeably improve employment prospects for those taking part. On the other hand, the findings include a number of programmes which appear to have had almost no effect. Programmes with fairly specific targeting have managed positive results and this may be due to the fact that these programmes usually take account of individual requirements. However, a number of programmes that were most widely targeted have had little impact. Lastly, to establish the ways in which programmes can be made better, more research is necessary. 
According to the findings of the logistic regression for the Regions of Crete and the Ionian Islands, the results for gender, marital status and place of residence are mixed. On the contrary, regarding age groups, the findings are common and clear except the age group of 25-34 in the Ionian Islands.

The level of education is statistically non-significant for 1988 in both regions, apart from primary school graduates in Crete, who were less likely to be unemployed than university graduates. In 1992, only in the Ionian Islands the educational level is statistically significant with the exception of lyceum graduates; in Crete, all educational variables are non-significant.

All training variables are statistically non-significant for 1992 in both regions except the apprenticeship in the Ionian Islands but even this with negative effect as well (as already mentioned in section 10, we cannot explore training in 1988 due to the limitations of data); so, the results of the logistic regression confirm the conclusions of the various studies for the limited impact of vocational training in Greece (see on the vocational training policies for the unemployed in Greece).

The results of educational and training variables are not compatible with the human capital theory, so the more educated and the more trained persons did not improve their position on the labour market in Crete and the Ionian Islands during the time period of the CSF-1. One explanation could be the fact that the tourist sector plays a major role in the economy of the regions under examination and so very often higher education is not necessary for the local manpower to find a job. Also, the labour market of the examined regions, like most of the highly attractive Greek tourist destinations, is characterised by high levels of seasonal employment. However, in 1992 in the Ionian Islands, we observe that TEI and high-school graduates were exceptions to the above mentioned finding, since they were more likely to be unemployed than people with a university degree. Consequently, investigation of the subsequent years is needed in order to have a clearer picture of the 1990s given the fact that, as mentioned in the introduction, the Greek LFS micro-data are now available to researchers.

Finally, the results of the interaction effect analysis show again that training is statistically non-significant in relation to both urbanisation level and level of education in both regions.

The research would merit attention of a wider international readership, since the paper does offer results that are useful for comparative research among European regions. Also, the study will be valuable to those who are interested in designing and implementing training programmes for structural change investigating the deficiencies and inefficiencies which have occurred in the Greek case. 


\section{References}

AAKVIK, A.; DAHL, S. 2006. Transitions to employment from labour market enterprises in Norway. International Journal of Social Welfare. 2006, vol. 15, no. 2, pp. 121-130.

ALBRECHT, J.; VAN DEN BERG, G. J.; VROMAN S. 2005. The knowledge lift: The Swedish Adult Education Program that aimed to eliminate low worker skill levels. IZA Discussion Paper 1503, Bonn.

ARELLANO, F. A. 2005. Do training programmes get the unemployed back to work? A look at the Spanish experience. Working Paper 05-25, Economics Series 15, Departamento de Economia, Universidad Carlos III de Madrid.

BALOURDOS, D.; CHRYSSAKIS, M. 1998. Programmes of continuing vocational training: Statistical indications, evaluation and perspectives (in Greek). In MARATOU-ALIPRANTI, L.; HATZIGIANNI, A. (eds.). Unemployment, employment, education-training in Greece and France. Proceedings of the Franco-Hellenic Colloquium, EKKE, Athens, pp. 133-150.

BECKER, G. S. 1962. Investment in human capital: A theoretical analysis. Journal of Political Economy. 1962, vol. 70 (supplement), October, pp. 9-49.

BECKER, G. S. 1964. Human capital. New York: Columbia University Press, 1964.

BECKER, G. S. 1975. Human capital: A theoretical and empirical analysis with special reference to education. 2. ed. New York: Columbia University Press, 1975.

BERMAN, E.; BOUND, J.; GRILICHES, Z. 1994. Changes in the demand for skilled labor within US manufacturing industries: Evidence from the annual survey of manufacturing. Quarterly Journal of Economics. 1994, CK, pp. 367-398.

BJORKLUND, A.; REGNER, H. 1996. Experimental evaluation of European labour market policy. In SCHMID, G.; O'REYLLY, J.; SCHOMANN, K. (eds.). International Handbook of Labour Market Policy and Evaluation. Aldershot, UK: Edward Elgar, pp. 89-114.

BLAUG, M. 1975. The empirical status of human capital theory. Journal of Economic Literature. 1975, vol. 14 , s. 827-855.

BONNAL, L.; FOUGERE, D.; SERANDON, A. 1994. L'impact des dispositifs d'emploi sur le devenir des jeunes chomeurs: Une evaluation econometrique sur donaces longitudinales. Economie et Prevision. 1994, vol. 115, pp. 1-28.

BRODATY, T.; CREPON, B.; FOUGERE, D. 2001. Using matching estimators to evaluate alter $\neg$ native youth employment programs: Evidence from France, 1986-1988. In LECHNER, M.; PFEIFFER, F. (eds.). Econometric evaluation of labour market policies. Heidelberg : Physica, 2001.

CALMFORS, L. 1994. Active labour market policy and unemployment: A framework for the analysis of crucial design features. OECD Economic Studies. 1994, no. 22, spring, pp. 7-47.

CALMFORS, L. 1995. What can we expect from active labour market policy? The Institute for International Economic Studies, reprint series, no. 546. University of Stockholm, 1995.

CALMFORS, L.; SKEDINGER, P. 1995. Does active labour-market policy increase employment? Theoretical considerations and some empirical evidence from Sweden. Oxford Review of Economic Policy. 1995, vol. 11, no. 1, pp. 91-109.

CARD, D.; SULLIVAN, D. 1988. Measuring the effect of subsidized training programs on movements in and out of employment. Econometrica. 1988, vol. 56, pp. 497-530.

CAVACO, S.; FOUGERE, D.; POUGET, J. 2005. Estimating the effect of a retraining program for displaced workers on their transition to permanent jobs. IZA Discussion Paper 1513, Bonn.

CEDEFOP 1998. Socio-economic framework of vocational education and training. In Training for a changing society. A report on current vocational education and training research in Europe, Part II, reference document, Thessaloniki, Brussels/Luxembourg, pp. 33-116.

CENTENO, L.; CENTENO, M.; NOVO, A. A. 2005. Evaluating the impact of a mandatory job search program: Evidence from a large longitudinal data set (mimeo)

CHLETSOS, M. 1998. The education as an active employment policy: Limits and preconditions of implementation. The case of Greece (in Greek). In MARATOU-ALIPRANTI, L.; HATZIGIANNI, A. (eds.). Unemployment, employment, education-training in Greece and France. Proceedings of the Franco-Hellenic Colloquium, EKKE, Athens, pp. 151-179.

CHRISTODOULAKIS, N.; KALYVITIS, S. 1995. Likely effects of the CSF 1994-1999 on the Greek economy. Discussion Paper No 46, KEPE, Athens. 
COCKX, B. 2003. Vocational training of unemployed workers in Belgium. Applied Economics Quarterly. 2003, vol. 49, no. 1, pp. 23-48.

COCKX, B.; VAN DER LINDEN, B.; KARAA, A. 1998. Active labour market policies and job tenure. Oxford Economic Papers. 1998, vol. 50, pp. 685-708.

CUETO, B.; MATO, F. J. 2009. A non-experimental evaluation of training programmes: Regional evidence for Spain. The Annals of Regional Science. 2009, vol. 43, no. 2, pp. 415-433.

DOLTON, P.; VIGNOLES, A. 2000. The incidence and effects of over-education in the UK graduate labour market. Economics of Education Review. 2009, vol. 19, no. 2, pp. 179-198.

Economic and Social Committee of Greece. 1998. Opinion of Initiative for the "Vocational Training", Athens, June (in Greek).

ESYE (National Statistical Service of Greece, 1988-2003). Statistical Yearbook and Labour Force Survey.

EUROSTAT. 1995. Education and employment prospects.

FAY, R. 1996. Enhancing the effectiveness of active labour market policies: Evidence from programme evaluations in OECD countries. Labour Market and Social Policy occasional papers, no. 18. Paris: OECD, 1996.

FELSTEAD, A.; GREEN, F.; MAYHEW, K. 1998. Interpreting training statistics in Europe: Issuing a health warning. European Journal of Vocational Training. 1998, no. 14, pp. 62-69.

FITZENBERGER, B.; SPECKESSER, S. 2005. Employment effects of the provision of specific professional skills and techniques in Germany. Department of Economics, Goethe-University, Frankfurt (mimeo).

GERFIN, M.; LECHNER, M. 2000. Micro-econometric evaluation of the active labour market policy in Switzerland. IZA Discussion paper No 154, Bonn.

GLYTSOS, N. P. 1990. Modeling future higher education-labour market imbalances: A multi-scenario approach. Economics of Education Review. 1990, vol. 9, no. 1, pp. 1-23.

GRAVARIS, D. 1991. The politico-economic foundations of employment policies (in Greek). Topos: Review of Urban and Regional Studies, No 4, Athens.

GRAVERSEN, B. 2004. Employment effects of active labor market programs: Do the programs help welfare benefit recipients to find jobs? PhD thesis, Department of Economics, University of Aarhus.

GRAVERSEN, B.; JENSEN, P. 2004. A re-appraisal of the virtues of private sector employment programs, Chapter 3. In GRAVERSEN, B.; GREEN, F.; FELSTEAD, A.; GALLIE, D. 1998. Changing skill-intensity: An analysis based on job characteristics. Working paper.

GREEN, F.; McINTOSH, S.; VIGNOLES, A. 1999. Over-education and skills - Clarifying the concepts. Discussion Paper No 435, CEP, LSE.

GRITZ, M. R. 1993. The impact of training on the frequency and duration of employment. Journal of Econometrics. 1993, vol. 57, no. 1-3, pp. 21-52.

GROOT, W.; VAN DEN BRINK, H. M. 1997. Allocation and the returns to over-education in the UK. Education Economics. 1997, vol. 5, pp. 169-183.

HAM, J. C.; LaLONDE, R. J. 1991. Estimating the effect of training on employment and unemployment durations: Evidence from experimental data. Working Paper No 3912, NBER, Cambridge, MA.

HÄMÄLÄINEN, K.; OLLIKAINEN, V. 2004. Differential effects of Active Labor Market Programmes in the early stages of young people's unemployment. VATT Research Reports 115, Helsinki.

HARTOG, J. 1997. On returns to education: Wandering along the hills of ORU land. Keynote speech for the LVIIth Conference of the Applied Econometrics Association, Maastricht, May.

HECKMAN, J. J.; LaLONDE, R. J.; SMITH, J. A. 1999. The economics and econometrics of active labour market programs. In ASHENFELTER, O.; CARD, D. (eds.). Handbook of Labor Economics. Vol. 3A. Amsterdam: Elsevier, 1999, pp. 1865-2097.

HOGELUND, J.; HOLM, A. 2005. Returning the long-term sick-listed to work: The efforts of educational measures and employer separations in Denmark. In SAUNDERS, P. (ed.). Welfare to Work in Practice. Social Security and Participation in Economic and Social Life. International Studies on Social Security. Vol. 10. Aldershot : Ashgate, 2005. 
HUJER, R.; THOMSEN, S.; ZEISS, C. 2004. The effects of vocational training programmes on the duration of unemployment in Eastern Germany. IZA Discussion Paper 1117, Bonn.

ILIADES, N. 1995. Continuing vocational training in Greece, National Report (in the context of FORCE). National Institute of Labour, January (in Greek).

IN.E./GSEE (Institute of Labour/General Confederation of Workers of Greece) - ADEDY (Civil Servants' Supreme Administrative Council). 1999. The Greek economy and the employment. Annual Report, Reports No 1. Athens, August (in Greek).

JACKMAN, R. 1995. What can active labour market policy do? Discussion Paper No 226, CEP, LSE.

JACKMAN, R.; LAYARD, R.; NICKELL, S. 1996. Combating unemployment: Is flexibility enough? (Discussion Paper No 293), CEP, LSE.

JOHNES, G.; TAYLOR, J.; FERGUSON, G. 1987. The employability of new graduates: A study of differences between UK universities. Applied Economics. 1987, vol. 19, s. 695-710.

KAITZ, H. B. 1979. Potential use of Markov process models to determine program impact. In BLOCH, F. E. (ed.). Research in labour economics. Greenwich, CT : JAI Press, 1979.

KANELLOPOULOS, C. 1984. Education and labour market in Greece (in Greek). In Implications of technological and scientific revolution. Athens : TEl of Athens, 1984, pp. 108-115.

KATSIKAS, Ch. 2005. Studies-Vocation and labour market, Atrapos (in Greek).

KLUVE, J.; SCHMIDT, C. M. 2002. Can training and employment subsidies combat European unemployment? Economic Policy. A European Forum. Issue 35, October, pp. 411-448.

KLUVE, J.; LEHMANN, H.; SCHMIDT, C. M. 1999. Active labour market policies in Poland: Human capital enhancement, stigmatization, or benefit churning? Journal of Comparative Economics. 1999, vol. 27, no. 1, pp. 61-89.

KLUVE, J.; LEHMANN, H.; SCHMIDT, C.M. 2005. Disentangling treatment effects of Active Labor Market Policies: The role of labor force status sequences. RWI Essen (mimeo).

KRUEGER, A. B.; SUMMERS, L. H. 1987. Reflections on the inter-industry wage structure. In LANG, K.; LEONARD, J. (eds.). Unemployment and the structure of labour markets. Oxford : Basil Blackwell, 1987, pp. 17-47.

LECHNER, M. 2000. An evaluation of public sector sponsored continuous vocational training programs in East Germany. Journal of Human Resources. 2000, vol. 35, pp. 347-375.

LECHNER, M.; MIQUEL, R.; WUNSCH, C. 2005. Long run effects of public sector sponsored training in West Germany. CEPR Discussion Paper 4851.

LECHNER, M.; MIQUEL, R.; WUNSCH, C. 2007. The curse and blessing of training the unemployed in a changing economy: The case of East Germany after unification. German Economic Review. 2007, vol. 8, November, pp. 468-509.

LEETMAA, R.; VÖRK, A. 2004. Evaluation of Active Labor Market Programmes in Estonia. PRAXIS Tallinn (mimeo).

LINARDOS-RYLMON, P. 1998. Vocational training and labour market: Indispensable changes into the function of the continuing training system in Greece (in Greek). In MARATOU-ALIPRANTI, L.; HATZIGIANNI, A. (eds.). Unemployment, employment, education-training in Greece and France. Proceedings of the Franco-Hellenic Colloquium, EKKE, Athens, pp. 233-236.

LORENTZEN, T.; DAHL, E. 2005. Active labour market programmes in Norway: Are they helpful for social assistance recipients? International Journal of Social Welfare. 2005, vol. 14, no. 2, pp. 86-98.

MACHIN, S. 1996. Wage inequality in the UK. Oxford Review of Economic Policy. 1996, vol. XII, pp. 47-64.

MACHIN, S.; VAN REENEN, J. 1998. Technology and changes in skill structure: Evidence from seven OECD countries. The Quarterly Journal of Economics. 1998, November, pp. 1215-1244.

MALMBERG-HEIMONEN, I.; VUORI, J. 2005. Activation or discouragement - The effect of enforced participation on the success of job-search training. European Journal of Social Work. 2005, vol, 8 , no. 4, pp. 451-467.

MATO, F. J.; CUETO, B. 2008. Un analisis de los effectos de las politicas de formacion a desempleados, Rev. Econ. Apl. www.revecap.com/revista/aceptados/matocueto.pdf (in press).

MEGHIR, C.; IOANNIDES, Y.; PISSARIDES, C. 1989. Female participation and male unemployment duration in Greece. European Economic Review. 1989, vol. 33, pp. 395-406. 
MURRAY, A.; STEEDMAN, H. 1998. Growing skills in Europe: The changing skills profiles of France, Germany, the Netherlands, Portugal, Sweden and the UK, TSER. Discussion Paper No 399, CEP, LSE.

OECD. 1990. Employment Outlook. Paris: OECD, 1990.

OECD. 1993a. Active labour market policies: Assessing macro-economic and micro-economic effects. Employment Outlook, ch. 2. Paris : OECD, 1993, pp. 39-80.

OECD. 1993b. Employment Outlook. Paris : OECD, 1993.

OECD. 1999. Employment Outlook. Paris : OECD, 1999.

PAPAKONSTANTINOU, G. 1998. Education-training as factors of investment in human capital (in Greek). In MARATOU-ALIPRANTI, L.; HATZIGIANNI, A. (eds.). Unemployment, employment, education-training in Greece and France. Proceedings of the Franco-Hellenic Colloquium, EKKE, Athens, pp. $125-132$.

PRAIS, S. J. 1995. Productivity, education and training: An international perspective. National Institute for Economic and Social Research. Cambridge : Cambridge University Press, 1995.

RAAUM, O.; TORP, H. 2002. Labour market training in Norway: Effect on earnings. Labour Economics. 2002, vol. 9, no. 2, pp. 207-247.

REES, A. 1973. The economics of work and pay. New York : Harper and Row, 1973.

REGNER, H. 2002. A non-experimental evaluation of training programmes for the unemployed in Sweden. Labour Economics. 2002, vol. 9, no. 2, pp. 187-206.

RIDDER, G. 1986. An event history approach to the evaluation of training, recruitment and employment programmes. Journal of Applied Econometrics. 1986, vol. 11, pp. 109-126.

RODOKANAKIS, S. 2009a. Investigating the unemployment risk in Greece from the LFS individual anonymised records: The case of Central Macedonia. The Empirical Economics Letters. 2009, vol. 8, no. 1, January, pp. 35-43.

RODOKANAKIS, S. 2009b. Comparing the probability of unemployment in Southern Greece vis-à-vis the entire country. Bulletin of Geography-Socio-economic Series. 2009, no. 12, pp. 17-43.

RODOKANAKIS, S. 2010a. The dynamics of regional labour markets and training programmes: Greek evidence. European Spatial Research and Policy. 2010, vol. 17, no. 1.

RODOKANAKIS, S. 2010b. Comparing the probability of unemployment in Northern Greece vis-à-vis the entire country. Journal of Economic Asymmetries. 2010, vol. 7, no. 1, pp. 139-76.

RODOKANAKIS, S.; MOUSTAKI, I. 2010. Evaluating the risk of unemployment: Comparison between the two most populated Greek regions with the entire country. Regional Science Inquiry Journal. 2010, no 1.

RODOKANAKIS, S.; TRYFONIDIS, D. 2009. Unemployment hazard in the Aegean islands: Econometric analysis of the LFS micro-data. In BROX, J. A.; BALTAS, N. (eds.). The global economics of a changing environment: Studies in the structure, performance and reform of economics, organizations and business throughout the globe, chapter 14. Waterloo, Canada : North Waterloo Academic Press, 2009, pp. 211-24.

ROSHOLM, M.; SKIPPER, L. 2003. Is labour market training a curse for the unemployed? Evidence from a social experiment. IZA Discussion paper No 716, Bonn.

ROSHOLM, M.; SVARER, M. 2004. Estimating the threat effect of Active Labor Market Programs. Working Paper No 6, Department of Economics, University of Aarhus.

SANYAL, B. C. 1987. Graduate unemployment and education. In PSACHAROPOULOS, G. (ed.). Economics of education: Research and studies. Education and Employment - Part IV. Pergamon Press, 1987, pp. 172-179.

SLOANE, P. J.; BATTU, H.; SEAMAN, P. T. 1995. Over-education and the formal education/experience and training trade-off. Discussion Paper 95-08, Department of Economics, University of Aberdeen.

STANLEY, M.; KATZ, L.; KRUEGER, A. B. 1999. Impacts of employment and training programs: The American experience. Harvard University (mimeo).

STEIGER, H. 2005. Is less more? A look at non-participation in Swiss active labor market programmes. University of St. Gallen (mimeo).

STENBERG, A. 2005. Comprehensive education for the unemployed - Evaluating the effects on unemployment of the Adult Education Initiative in Sweden. Labour. 2005, vol. 19, pp. 123-146. 
TORP, H. 1994. The impact of training on employment: Assessing a Norwegian labour market programme. Scandinavian Journal of Economics. 1994, vol. 96, pp. 531-550.

VAN OURS, J. C. 2001. Do active labour market policies help unemployed workers to find and keep regular jobs? In LECHNER, M.; PFEIFFER, F. (eds.). Econometric evaluation of labour market policies. Heidelberg : Physica, 2001.

WEBER, A.; HOFER, H. 2003. Active job-search programs a promising tool? A micro-econometric evaluation for Austria. IHS working paper, Economic Series 131, Vienna.

WINTER-EBMER, R. 2006. Coping with a structural crisis: Evaluating an innovative redundancy-retraining project. International Journal of Manpower. 2006, vol. 27, no. 8, pp. 700-721.

WOODHALL, M. 1987. Economics of education: A review. In PSACHAROPOULOS, G. (ed.). Economics of education: Research and studies. Pergamon Press, pp. 1-8.

www.economics.gr.

ZWEIMULLER, J.; WINTER-EBMER, R. 1996. Manpower training programmes and employment stability. Economica. 1996, vol. 63, no. 249, pp. 13-30.

\section{A NON-EXPERIMENTAL EVALUATION OF UNEMPLOYMENT RISK IN CRETE AND THE IONIAN ISLANDS: REGIONAL EVIDENCE FOR GREECE}

Abstract: The basic aim of this paper is to investigate the impact that individuals' level of education and participation in training programmes (apprenticeship, intra-firm training, continuing vocational training, popular training) have on their job prospects in Crete and the Ionian Islands, both among Greece's top tourist destinations, during the implementation of the first Community Support Framework - CSF (1989-1993). We try to see whether the level of education itself and participation in training programmes increased the chances of finding a job. More specifically, we examine the social and demographic characteristics that increase the chances of someone in the examined population finding a job, how those chances change (if they do) after the introduction of training courses and, also, whether university graduates, in contrast to most of the rest of the EU member states, face greater difficulties in finding a job than non-university graduates, as a series of studies for Greece conclude. In our analysis we use individual anonymised records (micro-data) of the Labour Force Survey (LFS) for both employed and unemployed at NUTS-2 level.

Keywords: Spatial econometrics; Labour economics policies; Human capital; Skills; Regional, urban and rural analyses

JEL Classification: C21, J08, J24, O18 